\title{
2'-Deoxycytidine As A Potential Biomarker For Detection Of Heptocellular Carcinoma
}

\author{
Wafaa Abdallah Ahmed ${ }^{1}$, Manar Moneer ${ }^{2}$, Maha M. Abo-Shady ${ }^{3}$, \\ Heba Hosny Mansour ${ }^{4}$, Nahed Abd-El-Wahab ${ }^{5}$, Masanori Yoshioka ${ }^{6}$, \\ Mahmoud El-Merzabani ${ }^{{ }^{*}}$
}

${ }^{1}$ Department of Cancer Biology (*Chemotherapy Unit), ${ }^{2}$ Department of Epidemiology and Biostatistics, ${ }^{5}$ Department of Clinical Pathology National Cancer Institute, Cairo University, Cairo, Egypt. ${ }^{3}$ Microbiology \& Immunology department, Faculty of pharmacy (girls), Al-Azhar University, ${ }^{4}$ Health Radiation Research Department, National Center for Radiation Research and Technology, (NCRRT), ${ }^{6}$ Department of Analytical Chemistry, Faculty of Pharmaceutical

Science, Setsunan University, Osaka, Japan.

\begin{abstract}
:
Background: 2'-deoxycytidine (Dcyd) is one of four major nucleosides found in the different normal body fluids due to dissolution of dead cells, and is increase in the presence of malignancy. Previous studies proved that it can be used as a marker for bladder cancer and acute lymphoblastic leukemia. The aim of this study is to assess 2'Dcyd as a possible biological marker in hepatocellular carcinoma (HCC).

Methods: Four groups were evaluated for the level 2'-Dcyd as well as alpha-fetoprotein (AFP); a control group $(\mathrm{n}=20), 20$ cases of chronic liver diseases (CLD), 20 cases of hepatitis $\mathrm{C}(\mathrm{HCV}) 60$ cases of HCC.

Results: In the patients with HCC, 2'-Dcyd serum level was 8-fold higher than normal level. It was 3-fold higher in HCV group. A mild increase was noted in patients with chronic liver diseases. Levels $\geq 0.14$ of 2'-Dcyd had a sensitivity of $93 \%$ and specificity of $90 \%$ for diagnosis of HCC. It also recorded a sensitivity and specificity of $90 \%$ for diagnosis of HCV.

Conclusions: For diagnosis of HCC, 2'-Dcyd is no better than AFP, as it is elevated in viral hepatitis C. A combination of AFP and 2'-Dcyd could provide broader information in diagnosis and treatment decision.
\end{abstract}

\section{Introduction:}

Worldwide, hepatocellular carcinoma (HCC) is one of the most common malignancies associated with poor prognosis (Okano et al., 2001). According to recent reports, the incidence of $\mathrm{HCC}$ has increased sharply in the last 5-10 years (El-Serag, 2002; Velazquez et al., 2003; Bruix et al., 2001). In USA, the rate of HCC has increased by $70 \%$ over the last two decades. Registry data in Canada and Western Europe show similar trends (Yu et al., 2000). In Egypt, El-Zayadi et al. (2005) reported a rising trend of $\mathrm{HCC}$ with increasing risk among $\mathrm{HCV}$-infected men of older age groups. They recommended; careful followed-up of patients and screening for early detection of HCC. In Egypt, HCC was reported to account for about $4.7 \%$ of chronic liver disease (CLD) patients (El-Zayadi et al., 2001).

Hepatocellular carcinoma (HCC) is the fifth most common malignancy in the world (El-Serag, 2002) complicating liver cirrhosis in most cases. Its incidence is increasing worldwide ranging between 3\% and $9 \%$ annually (Velazquez et al., 2003). The epidemiology of HCC is characterized by marked demographic and geographic variations. It is the third leading cause of cancer mortality in Sub-Saharan Africa and in the Far East and ranks second in China (Shiratori et al., 2001; Bosch et al., 1999; Schafer \& Sorrell, 1999).

More than $80 \%$ of $\mathrm{HCC}$ occurring worldwide is felt to be associated with chronic viral hepatitis (Donald et al., 2000). 
Hepatitis virus is the major cause of acute and chronic hepatitis, leading to progressive development of necroinflammatory changes in the liver, which can result in cirrhosis and hepatocellular carcinoma (Bryant et al., 2001; Hoofnagle et al., 1997) Egypt is a developing country where hepatitis B and C infection are still prevalent, the risk factor for viral transmission that specifically sets Egypt a part of other countries is a personal history of schistosomal infection (Huynh et al., 2002). Specific factors important for pathogenesis of HCC are incompletely understood, and treatment outcomes have generally remained poor (Actor et al., 1993).

Routine surveillance of persons at risk can result in successful treatment of HCC that is detected early with screening techniques. Both periodic serial determination of alpha-fetoprotein (AFP) and hepatic ultrasound (US) examination, alone or separately, have been used successfully resulting in a higher chance of successful treatment. Alpha-fetoprotein (AFP) is one of the earliest recognized oncofetal markers. It is produced in large amount by the fetal liver, but its expression reduces sharply at birth. AFP is synthesized by most hepatoblastomas and approximately half of hepatocellular carcinomas (Taketa et al., 1990), and widely used in differential diagnosis and follow-up of patients with liver tumors, but so far no correlation has been found between the clinical behavior and AFP production in HCC (Lee et al., 1991; Yao et al., 1999).

Tarao et al. (1999) studied the correlation between DNA synthesis of heptocytes and the development of HCC in vitro, they reported that $\mathrm{HCC}$ tended to develop or detectable when DNA synthesis of heptocyte was increased. 2'-deoxycytidine (Dcyd) is a major modified neuclosides found in the body fluids, the source of Dcyd is not only tumor cells but also the host liver cells can produce it via stimulating the biosynthesis of Dcyd nucleotides rather than enhanced degradation of DNA (Sozen et al., 1999; Staub et al., 1996).

Yoshioka et al. (1997) developed sensitive and accurate procedure for quantitative determination of Dcyd in body fluids. This method is simple and reproducible for possible use Dcyd in routine examination as a biomarker for tumor detection (Yoshioka et al., 1997; Michino et al., 1997; Omura et al., 1997; Aziz \& Wu, 2002). Previous studies on Dcyd in the National Cancer institute (NCI) in Egypt reported that it may be used in detection of breast cancer, acute lymphoblastic leukemia and bladder cancer where it showed high sensitivity in these tumors. In this study, we evaluate use of serum Dcyd as a biomarker for early detection of heptocellular carcinoma to avoid invasive biopsy.

\section{Subjects \& Methods Subjects:}

This study included 120 individuals; classified into four groups:

Group 1: Twenty apparently healthy individuals to serve as reference group (12 males and 8 females) their age ranged from 24 to 40 . There were volunteers from the staff members of cancer biology department, National cancer Institute, Cairo University.

Group 2: Twenty patients with chronic liver disease (14 males and 6 females) their age ranged from 34 to 63 .

Group 3: Twenty patients with hepatitis $C$ (16 males and 4 females) their age ranged from 24 to 60 .

Group 4: Sixty patients with hepatocellular carcinoma (49 males and 11 females) their age ranged from 29 to 70.

Patients with hepatitis $\mathrm{C}$ and chronic liver diseases were selected from Al- Zahra University Hospital, Al-Azhar University in June 2004. Patients with hepatocellular carcinoma were selected from inpatients of National Cancer Institute, Cairo University during the period from March 2004 to October 2004. Patients of all groups were subjected to full clinical evaluation. Sera of these patients were investigated for liver functions tests, alpha-fetoprotein (AFP), Creactive protein (CRP) and 2'-deoxycytidine (2'-Dcyd). Individual patient profiles were collected from medical records.

Serum 2'-Dcyd was determined according to Advanced Life Science Institute, Inc., Tokyo. 


\section{Reagents:}

Anti-Dcyd antibody coated micro plate (lot 0002) 96 wells store at $4^{\circ} \mathrm{C}$

Reaction Buffer (lot 0002) $200 \mathrm{ml}$ store at $4^{\circ} \mathrm{C}$

POD Conjugate (x 100 conc.) (lot 0002) $1 \mathrm{ml}$ store at $4^{\circ} \mathrm{C}$

Standard Dcyd (50 mM) (lot 0002)

$0.6 \mathrm{ml}$ store at $4^{\circ} \mathrm{C}$

Substrate Buffer (lot 0002) $80 \mathrm{ml}$ store at $4^{\circ} \mathrm{C}$

OPD tablet (lot 0002) 12 tab store at $4^{\circ} \mathrm{C}$

Stop solution $\left(2 \mathrm{~N} \mathrm{H}_{2} \mathrm{SO}_{4}\right)$ (lot 0002) $80 \mathrm{ml}$ store at $4^{\circ} \mathrm{C}$

Preparation of various reagents:

Reaction Buffer: pH 7.3 (1\% bovine serum albumin- $10 \mathrm{mM}$ EDTA- $0.1 \mathrm{M}$ potassium phosphate $-0.15 \mathrm{M} \mathrm{NaCl}-0.2 \%$ Triton X-100).

Substrate Buffer: $\mathrm{pH} \quad 5 \quad(0.05 \mathrm{M}$ phosphate Citrate Buffer).

Wash Buffer: pH 7.3 (10 mM sodium phosphate containing $0.15 \mathrm{M} \mathrm{NaCl}$ and $0.05 \%$ Tween-20).

Conjugate Solution: Mix OPD conjugate $1 / 100$ in reaction buffer.

Standard Solution: The concentration of standard solution $50 \mathrm{mM}$ diluted to 3 $\mathrm{mM}$ with reaction buffer, then, dilute $3 \mathrm{mM}$ solution serially 3 times with reaction buffer. Each standard is 0, 12.5, 33,111, 333, 1000, $3000 \mu \mathrm{M}$.

Stop Solution: $2 \mathrm{~N}$. $\mathrm{H}_{2} \mathrm{SO}_{4}$.

Other Reagents:

Anti-Dcyd monoclonal antibody.

Anti-Mouse IgG conjugated peroxidase.

O-phenylenediamine (OPD) tablets

(Sigma).

\section{Procedure:}

The kit components must be brought at room temperature before beginning assay.

Plate was removed from the pouch.

The first one well of the plate used as blank. $20 \mu \mathrm{l}$ of each standard or specimen were added into the other wells followed by $100 \mu 1$ of anti-Dcyd MoAb solution.

The reaction mixture was covered by seal and incubated at $37 \mathrm{c}$ for 90 minutes.

The content of each well was aspirated and washed by washing solution $(5$ cycles of $350 \mu 1 /$ well including blank well).
$100 \mu \mathrm{l}$ substrate solution were added into each well including blank well.

The mixture were incubated at room temperature (20-30c) for 30-33 minutes in the dark.

$100 \mu 1$ stop solution were added into each well including blank well, and shake plate calmly.

Readings were performed at $492 \mathrm{~nm}$ using a $600-700 \mathrm{~nm}$ reference wavelength for less than one hour after stop reaction. The optical density of blank well is 0.000 .

Prepare the calibration curve for Dcyd using the optical density of each standard Vs its log concentration. Calculate amount of Dcyd in specimens by the calibration curve.

CRP (C-reactive protein) was measured by Latex Agglutination Slide Test for CRP in serum, product No. 905041-E. Serum AFP was performed according to the package insert of the kit (Matritech, USA. AFP kit. Enzyme immune-assay).

Statistical analysis:

Statistical package for social sciences (SPSS, version 12) was used for data management. Numerical variables were presented as mean \pm standard deviation (SD), median, range. Qualitative variables were presented as frequency and percentage. Mann-Whitney $U$ test was used to test difference of numerical variables between two groups while ANOVA test was used on the rank of the numerical variables to test difference between more than 2 groups, followed by Sheffe test for pairwise comparison. Chi-Square test was performed to compare qualitative variables. $\mathrm{P}$ value less than 0.05 was considered significant and less than 0.001 was considered highly significant. For determination of cut-off levels ROC curve was applied.

\section{Results}

Clinical characteristics of the different studied groups are presented in table 1. It was noticed that all control cases were not cirrhotic, while one third of HCC group show ++ cirrhosis.

Liver enzymes (AST, ALT) and AFP were significantly higher in the three 
diseased groups compared to control group. It was noticed that levels of these markers were the highest in hepatocellular carcinoma group (table 2).

Serum levels of 2'-deoxycytidine were significantly higher in both HCV and HCC groups compared to the control group. On the contrary, in the CLD group no such a difference was observed $(\mathrm{p}=0.112)$ (table 1). C-reactive protein (CRP) was positive in $81.7 \%$ of $\mathrm{HCC}$ group and $60 \%$ in $\mathrm{HCV}$ group. It was positive in $15 \%$ of cases with chronic liver disease. In the control group, all cases were CRP -ve (table 1). This difference was statistically significant ( $\mathrm{p}<$ $0.001)$.

Within the HCC group, there was no difference between CRP positive and negative cases concerning the levels of liver enzymes, AFP as well as 2'-Dcyd (table 3). There was a significant correlation between detection of cirrhosis and elevation of AFP and liver enzymes. On the contrary, levels of 2'-Dcyd were not significantly different in cirrhotic cases in comparison to noncirrhotic cases within the HCC group (table 4). There was a significant correlation between 2'-Dcyd and AFP, ALT and AST ( $\mathrm{r}=0.6,0.5$ and 0.6 , respectively).

Table (1): Clinical data of the studied groups

\begin{tabular}{|l|l|l|l|l|l|}
\hline Groups & $\begin{array}{l}\text { Control } \\
(\mathrm{n}=20)\end{array}$ & $\begin{array}{l}\text { HCC } \\
(\mathrm{n}=60)\end{array}$ & $\begin{array}{l}\text { CLD } \\
(\mathrm{n}=20)\end{array}$ & $\begin{array}{l}\text { HCV } \\
(\mathrm{n}=20)\end{array}$ & P value \\
\hline Age (years) & & & & & \\
\hline Mean+SD & $28.3 \pm 4.6^{\mathrm{a}}$ & $56.2 \pm 8.8^{\mathrm{b}}$ & $62.0 \pm 9.1^{\mathrm{b}}$ & $42 \pm 11.9^{\mathrm{c}}$ & \\
\hline Range & $21-40$ & $36-72$ & $43-80$ & $24-62$ & $<0.001$ \\
\hline Sex & $11 / 9$ & $44 / 16$ & $15 / 5$ & $16 / 4$ & \\
\hline Males & $11(55 \%)$ & $44(73.3 \%)$ & $15(75 \%)$ & $16(80 \%)$ & 0.307 \\
\hline Females & $9(45 \%)$ & $16(26.7 \%)$ & $5(25 \%)$ & $4(20 \%)$ & \\
\hline Cirrhosis Degree & & & & & \\
\hline -ve & $20(100 \%)$ & $25(41.7 \%)$ & $10(50 \%)$ & $16(80 \%)$ & \\
\hline+ ve & 0 & $15(25.0 \%)$ & $10(50 \%)$ & $4(20 \%)$ & $<0.001$ \\
\hline$++\mathrm{ve}$ & 0 & $20(33.3 \%)$ & 0 & 0 & \\
\hline
\end{tabular}

Table (2): Laboratory data of the studied groups

\begin{tabular}{|c|c|c|c|c|c|}
\hline Groups & $\begin{array}{l}\text { Control } \\
(\mathrm{n}=20)\end{array}$ & $\begin{array}{l}\mathrm{HCC} \\
(\mathrm{n}=60)\end{array}$ & $\begin{array}{l}\text { CLD } \\
(\mathrm{n}=20)\end{array}$ & $\begin{array}{l}\text { HCV } \\
(\mathrm{n}=20)\end{array}$ & $\mathrm{P}$ value \\
\hline \multicolumn{6}{|l|}{ ALT } \\
\hline Mean+SD & $8.1 \pm 2.5^{\mathrm{a}}$ & $114.1 \pm 91.2^{\mathrm{b}}$ & $44.6 \pm 21^{\mathrm{c}}$ & $49.8 \pm 16.9^{\mathrm{c}}$ & $<0.001$ \\
\hline Median (Range) & $8(4-12)$ & 78 (13-394) & $42(15-92)$ & $43(27-80)$ & \\
\hline \multicolumn{6}{|l|}{ AST } \\
\hline Mean+SD & $8.8 \pm 2.5^{\mathrm{a}}$ & $129.1 \pm 95.6^{\mathrm{b}}$ & $56.2 \pm 27^{\mathrm{c}}$ & $34.7 \pm 11.7^{\mathrm{c}}$ & $<0.001$ \\
\hline Median (Range) & $9(4-13)$ & $111(22-440)$ & $61(26-90)$ & $32(18-66)$ & \\
\hline \multicolumn{6}{|l|}{ AFP } \\
\hline Mean+SD & $1.6 \pm 0.78^{\mathrm{a}}$ & $2717.1 \pm 633.7^{b}$ & $8.5 \pm 9.2^{\mathrm{c}}$ & $4.1 \pm 2.0^{c}$ & $<0.001$ \\
\hline Median (Range) & $1.45(0.6-3.2)$ & $296.5(2-31000)$ & $5.0(1.3-39)$ & $3.25(1.8-10)$ & \\
\hline \multicolumn{6}{|l|}{ 2'-Dcyd } \\
\hline Mean+SD & $0.07 \pm 0.06^{\mathrm{a}}$ & $0.58 \pm 0.85^{\mathrm{b}}$ & $0.14 \pm 0.06^{\mathrm{a}}$ & $0.23 \pm 0.07^{\mathrm{c}}$ & $<0.001$ \\
\hline Median (Range) & $\begin{array}{ll}0.05 & (0.004- \\
0.21) & \\
\end{array}$ & $0.29(0.04-5.2)$ & $0.16(0.03-0.23)$ & $\begin{array}{ll}0.25 & (0.1- \\
0.38) & \end{array}$ & \\
\hline \multicolumn{6}{|l|}{ CRP } \\
\hline+ +ve [No. (\%)] & $0(0 \%)$ & $49(81.7 \%)$ & $4(20 \%)$ & $12(60 \%)$ & $<0.001$ \\
\hline
\end{tabular}

HCC: Hepatocellular carcinoma, CLD: Chronic liver disease, HCV: Hepatitis C-Virus

2'-Dcyd: 2/-Deoxycitidine

Groups with different letters are significantly different from each other 
Table (3): Relation between CRP positivity and other investigated parameters in HCC group

\begin{tabular}{|l|l|l|l|l|}
\hline \multicolumn{2}{|c|}{} & CRP & \multirow{2}{*}{-value } \\
\cline { 3 - 4 } & $\begin{array}{l}\text { Negative } \\
(\mathrm{n}=11)\end{array}$ & $\begin{array}{l}\text { Positive } \\
(\mathrm{n}=49)\end{array}$ & \\
\hline 2'-Dcyd & Mean \pm SD & $0.38+0.15$ & $0.62+0.94$ & \multirow{2}{*}{0.633} \\
\hline & Median (Range) & $0.29(0.19-0.61)$ & $0.29(0.04-5.2)$ & \\
\hline AFP & Mean \pm SD & $3131+6905$ & $2626+6272$ & \multirow{2}{*}{0.417} \\
\hline & Median (Range) & $1127(4-23670)$ & $220(2-31000)$ & \multirow{2}{*}{0.709} \\
\hline AST & Mean \pm SD & $149.9+122$ & $125+89.6$ & \multirow{2}{*}{0.379} \\
\hline & Median (Range) & $109(30-440)$ & $113(22-328)$ & \\
\hline ALT & Mean \pm SD & $131+105.6$ & $110+88.3$ & $77(13-337)$ \\
\hline & Median (Range) & $79(31-394)$ & &
\end{tabular}

Table (4): Relation between cirrhosis and other investigated parameters in HCC group

\begin{tabular}{|l|l|l|l|l|}
\hline \multicolumn{2}{|c|}{} & Cirrhosis & \multirow{2}{*}{-value } \\
\cline { 3 - 5 } \multicolumn{2}{|l|}{} & $\begin{array}{l}\text { Negative } \\
(\mathrm{n}=25)\end{array}$ & $\begin{array}{l}\text { Positive } \\
(\mathrm{n}=35)\end{array}$ & \multirow{2}{*}{0.418} \\
\hline 2'-Dcyd & Mean \pm SD & $0.75 \pm 1.1$ & $0.45 \pm 0.56$ & \multirow{2}{*}{0.001} \\
\hline & Median (Range) & $0.29(0.11-5.2)$ & $0.29(0.04-3.2)$ & \multirow{2}{*}{0.001} \\
\hline AFP & Mean \pm SD & $1511.3 \pm 480.9$ & $3578 \pm 717.4$ & \\
\hline & Median (Range) & $1174(4-31000)$ & $21(2-23670)$ & \multirow{2}{*}{0.001} \\
\hline AST & Mean \pm SD & $85.7 \pm 97.3$ & $160 \pm 82.4$ & $125(40-317)$ \\
\hline & Median (Range) & $52(22-440)$ & $133 \pm 79$ & \\
\hline ALT & Mean \pm SD & $87.6 \pm 101.6$ & $112(13-337)$ & \\
\hline & Median (Range) & $48(19-394)$ & &
\end{tabular}

Table (5): Sensitivity and specificity for different cut-off levels of 2'-Dcyd for different diagnoses

\begin{tabular}{|l|l|l|l|}
\hline Diagnosis & Suggested Cut-Off Values & Sensitivity & Specificity \\
\hline HCC & 0.13 & $93 \%$ & $85 \%$ \\
\hline & $0.14^{*}$ & $93 \%$ & $90 \%$ \\
\hline & 0.16 & $92 \%$ & $90 \%$ \\
\hline & 0.17 & $88 \%$ & $90 \%$ \\
\hline & 0.18 & $87 \%$ & $95 \%$ \\
\hline HCV & 0.13 & $90 \%$ & $85 \%$ \\
\hline & $0.14 *$ & $90 \%$ & $90 \%$ \\
\hline & 0.16 & $85 \%$ & $90 \%$ \\
\hline & 0.18 & $80 \%$ & $95 \%$ \\
\hline CLD & 0.13 & $60 \%$ & $85 \%$ \\
\hline & $0.14 *$ & $55 \%$ & $90 \%$ \\
\hline
\end{tabular}


2'-Deoxycytidine As A Potential Biomarker.

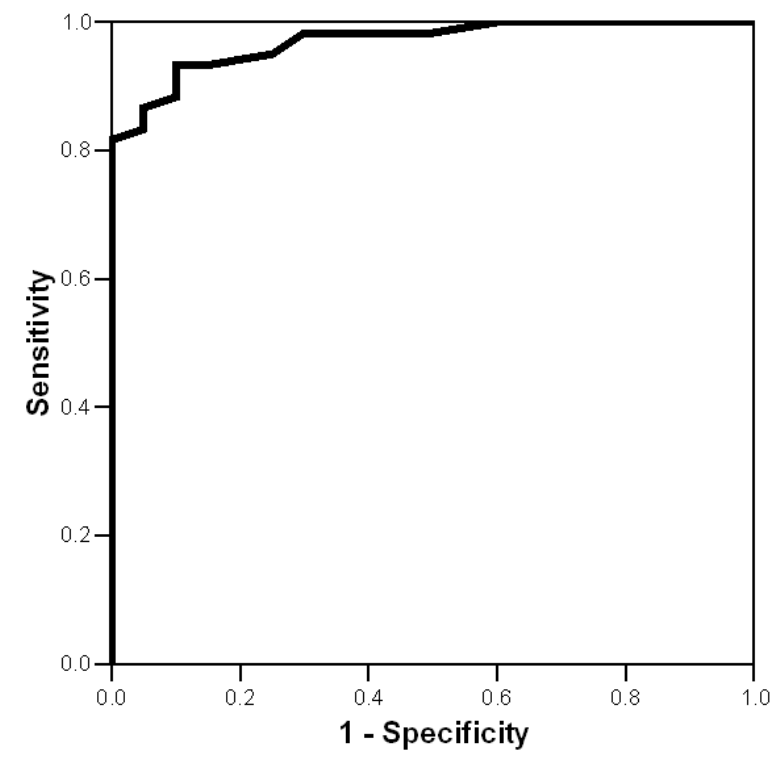

ROC Curve for diagnosis of HCC

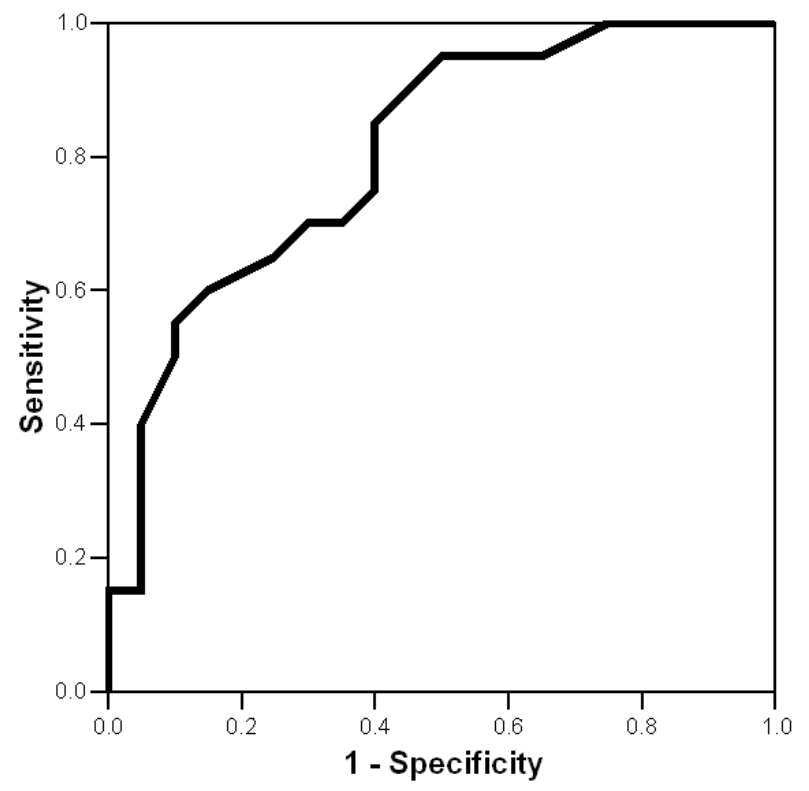

ROC Curve for diagnosis of CLD 


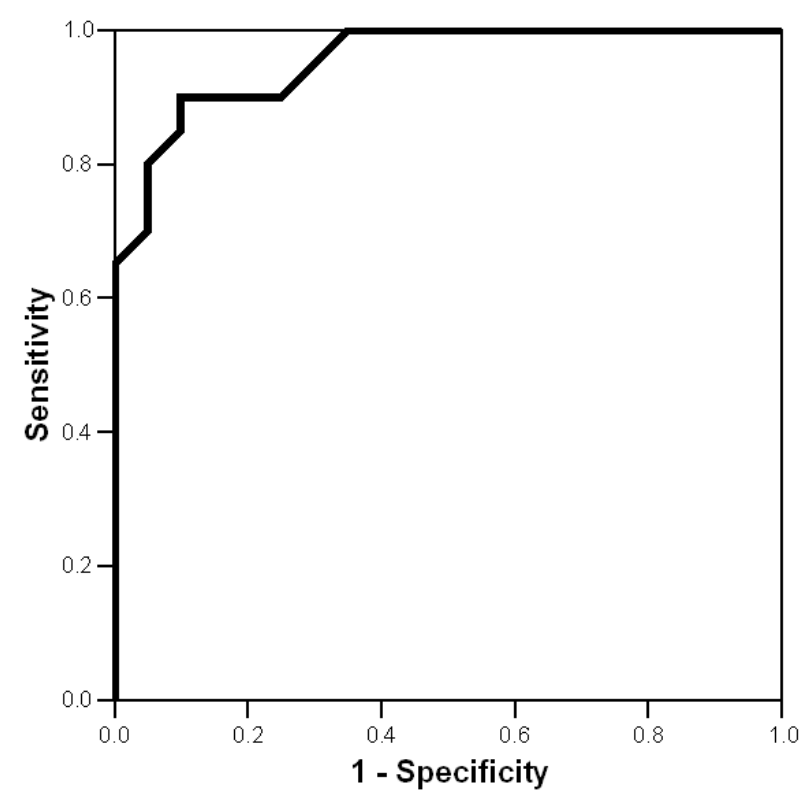

ROC Curve for diagnosis of $\mathrm{HCV}$

\section{Discussion:}

It is difficult to accurately diagnose early HCC. But early detection is still the only way to improve mortality. The disease is nearly fatal. The tumors are highly heterogeneous. In early-stage disease, where tumors are less than $2 \mathrm{~cm}$ in diameter, even expert radiologists have difficulty differentiating between a cirrhotic nodule and a malignant tumor. Liver cirrhosis is a precancerous condition that can develop into HCC (Wilson, 2005). Therefore, cirrhotic patients are usually screened for HCC during their follow-up procedure (Burtis et al., 2001).

Tumor markers are potential screening tools that are widely used for early diagnosis of tumors (Shu et al., 2002). Many research groups are evaluating the sensitivity of available tumor markers and also are investigating the development of a novel marker (Lim et al., 2002; Yoshida et al., 2002; Nakatsura et al., 2003). The primary marker for HCC is alphafetoprotein (AFP), a single polypeptide chain glycoprotein, its sensitivity and specificity are insufficient to detect HCC in all patient samples. AFP is not secreted in all cases of HCC and may be normal in as many as $40 \%$ of patients with early HCC (Di Bisceglie et al., 2005).

We evaluated a new biochemical factor 2'-Dcyd in addition to AFP to improve the detection of HCC and precancerous lesions hepatitis $\mathrm{C}$ and chronic liver diseases. 2'-deoxycytidine is one of four major nucleosides found in the different normal body fluids due to dissolution of dead cells, and it increases in the presence of malignancy and during chemotherapy (Wakui et al., 1986).

The results showed elevation in liver enzymes (AST, ALT) among patients with chronic liver diseases and hepatitis $\mathrm{C}$ in the absence of HCC. Whereas serum AFP levels were lower in CLD and HCV patients when compared to HCC group but still significantly higher than control cases. Di Bisceglie et al. (2005) reported that in patients with advanced chronic hepatitis $\mathrm{C}$, serum AFP values are frequently elevated, even in the absence of HCC. They also reported significant increase in serum AST and ALT among patients with chronic hepatitis $\mathrm{C}$ and advanced fibrosis. Similar 
results were obtained by Wakui et al. (1986), who reported a statistically significant elevation of the enzyme activity in patients with acute hepatitis, chronic hepatitis, liver cirrhosis, malignant liver diseases and obstructive jaundice.

The results showed a mild increase in serum levels of 2'-Dcyd in patients with chronic liver diseases and 3-fold increase in patients with $\mathrm{HCV}$. In the patients with HCC, 2'-Dcyd serum level was 8-fold higher than normal level. This agrees with the result of our previous study which revealed an increase of 2'-Dcyd level in serum with other malignancies (Abdellah et al., 2003).

We have studied the inflammatory marker (CRP) to determine its relation to 2'Dcyd, to see if its elevation can be attributed to malignancy alone or to other inflammatory conditions. CRP was positive in more than $80 \%$ of $\mathrm{HCC}$ patients. But, In HCC group there was no significant difference between serum 2'-Dcyd levels between cases with negative or positive CRP. So, we can conclude that elevation of 2'-Dcyd is mainly attributed to malignancy and not to an inflammatory process. Similarly, no statilstically significant difference was found between CRP positive and negative cases regarding levels of AFP, ALT and AST.

Cirrhosis was observed in $58 \%$ of HCC cases, $50 \%$ of CLD and only $20 \%$ of $\mathrm{HCV}$ cases. No significant difference in level of 2'-Dcyd between cirrhotic and noncirrhotic cases in HCC group. On the other hand, AFP and liver enzymes were significantly higher in cirrhotic cases. Similar results were reported by Kane et al. (1997) who showed that chronic inflammatory status of liver frequently increases liver enzymes, AFP and production of nitric oxide. They also reported that patients with positive HCV infection who developed HCC on top of cirrhosis showed high levels of AFP and liver enzymes far exceeded those of liver cirrhosis alone.

In this study, no relation could be found between increased levels of 2'-Dcyd and cirrhosis or the inflammatory process. Chronic liver disease was not associated with a significant rise in 2'-Dcyd compared to control individuals. This illustrates that this marker is related to damage of hepatocytes rather than inflammation or chronic liver insult. Unfortunately, it could not be considered specific to HCC, as it was high enough in cases of HCV.

Using ROC curves, it is suggested to use 0.14 of 2'-Dcyd as a cut-off level for diagnosis of HCC. This level had a sensitivity of $93 \%$ and specificity of $90 \%$. These levels were not higher than those of a AFP level of $\geq 3.55$, which had a sensitivity of $95 \%$ and specificity of $100 \%$. On the other hand, the same 2'-Dcyd level of 0.14 had a sensitivity and specificity of $90 \%$ for diagnosis of $\mathrm{HCV}$. When $\mathrm{HCV}$ cases are added to control cases, specificity of this cut-off level drops to $50 \%$.

We can conclude that for diagnosis of HCC, 2'-Dcyd is no better than AFP, as it is elevated in viral hepatitis C. A combination of AFP and 2'-Dcyd could provide broader information in diagnosis and treatment decision.

\section{References:}

1. Abdellah WA, Hassan N, Masanori Y, Mahmoud E (2003): 2'-deoxycytidine as potential biological marker for detecting acute lymphocytic leukemia and bladder cancer. J Union Arab Biol 20(A): 97-111.

2. Actor JK, Shirai M, Kulberg MC, Buller RML, Sher A, Berzofasky JA (1993): Helminth infection results in decrease virus-specific CD8+ cytotoxic T- cell and THI cytokine responses as well as delayed virus clearance. Proe Natt Acad USA 90:984-91.

3. Aziz K, Wu GY (2002) (Eds.) Cancer screening: A practical Guide for physician Totowa, NJ: Humana Press.

4. Bosch FX, Ribes J, Borras J (1999): Epidemiology of primary liver cancer. Semin Liver Dis 19:271-85.

5. Bruix J, Sherman M, Llovet JM, Beaugrand $M$, Lencioni $R$, Burroughs AK, Christensen E, Pagliaro L, Colombo M, Rodes J (2001): EASL Panel of Experts on HCC. Clinical management of hepatocellular carcinoma. Conclusions of the Barcelona-2000 EASL conference. J Hepatol 35: 421-430

6. Bryant ML, Bridges E, Placidi L, Faraj A, Loi AG, Pierra C, Dukhan D, Gosselin 
G, Imbach JL, Hernandez B, Juodawlkis A, Tennant B, Korba B, Cote P, Marion P, Cretton-Scott E, Schinazi RF, Sommadossi JP (2001): Antiviral Lnucleosides specific for hepatitis $\mathrm{B}$ virus infection. Antimicrob Agents Chemother 45:229-235.

7. Burtis CA, Ashwood ER (2001): Tietz Fundamentals of clinical chemistry. $5^{\text {th }}$ ed. Philadelphia, Pa: WB Saunders; 2001.

8. Di Bisceglie AM, Sterling RK, Chung RT, Everhart JE, Dienstag JL, Bonkovsky HL, Wright EC, Everson GT, Lindsay KL, Lok AS, Lee WM, Morgan TR, Gretch DR (2005): MALT-C Trial group. Serum alpha-fetoprotein levels in patients with advanced hepatitis $\mathrm{C}$ : results from the HALT-C Trial. J Hepatol 43(3): 434-41.

9. Donald K, Strickland, Caroline A (2000): Hepatitis C infection among survivors of childhood cancer. Blood 95 (10):3065-70.

10. El-Serag HB (2002): Hepatocellular carcinoma: an epidemiologic view. J Clin Gastroenterol 35(Suppl 2): S72-78

11. El-Zayadi AR, Abaza H, Shawky S, Mohamed MK, Selim OE, Badran HM (2001): Prevalence and epidemiological features of hepatocellular carcinoma in Egypt-a single center experience. Hepatol Res 19:170-179

12. El-Zayadi AR, Badran HM, Barakat EMF, Attia MED, Shawky S, Mohamed MK, Selim O, Saeid A (2005): Hepatocellular carcinoma in Egypt: A single center study over a decade. World J Gastroenterol 11(33): 5193-5198

13. Hoofnagle JH, Di Bisceglie AM (1997): The treatment of chronic viral hepatitis. N Engl J Med 336:347-356.

14. Huynh H, Chow PK, Ooi LL, So KC (2002): A possible role for insulin-like growth factor-binding protein 3 autocrine/paracrine loops in controlling heptocellular carcinoma cell proliferation. Cell Growth Differ 13 (3):115-122.

15. Kane JM, Shrars LL, Posner MC (1997): Chronic hepatitis $\mathrm{C}$ virus infection in human: induction of hepatic nitric oxide synthase and proposed mechanisms for carcinogenesis. J. Surg. Res. 69 (2): 32124.

16. Lee HS, Chung YH, Kim CY (1991): Specificities of serum alpha-fetoprotein levels in $\mathrm{HbsAg}+$ and HbsAg- patients in the diagnosis of hepatocellular carcinoma. Hepatology 14:68-72.
17. Lim SO, Park SJ, Kim W, et al. (2002): Proteome analysis of heptocullular carcinoma. Biochem Biophys Res Commum 291:1031-37

18. Michino M, Kunihiko L, Takahumi Y, Shunji H, Seishiro N, Nakao I (1997): Preparation of monoclonal antibody specific for 2'-deoxycitidine. Biol Pharm Bull 15(12):1537-40.

19. Nakatsura T, Yoshitake Y, Senju S, et al. (2003): Glypican-3 overexpressed specifically in human heptocellular carcinoma, is a novel tumor marker. Biochem Biophys Res Commum 306: 16-25.

20. Okano H, Shiraki K, Inoue H, Deguchi M, Sugimoto K, Sakai T, Ohmori S, Murata K, Nakano T, Yamakado K, Takeda K (2001): Treatment of hepatocellular carcinoma and the exacerbation of liver function. Int J Oncol 19:1279-1282.

21. Omura K, Hirose K, Itoh M, Akizawa T, Yoshioka M (1997): Development of enzyme immunoassay of 2'-deoxycitidine. J Pharm Biomed Anal 15(9-10): 1249-56.

22. Schafer DF, Sorrell MF (1999): Hepatocellular carcinoma. Lancet 353:1253-7.

23. Shiratori Y, Yoshida H, Omata M (2001): Different clinicopathological features of hepatocellular carcinoma in relation to causative agents. J Gastroenterol 36:73-8.

24. Shu HJ, Saito T, Watanabe H, et al. (2002): Expression of Musashi1 gene encoding in RNA-binding protein in human hepatoma cell line Biochem Biophys Res Commum 293:150-54.

25. Sozen S, Biri H, Sinik Z, Kupeli B, Alkibay T, Bozkirli I (1999): Comparison of the nuclear matrix protein 22 with voided urine cytology and BTA stat test in the diagnosis of transitional cell carcinoma of the bladder. Eur Urol. 36(3):225-9.

26. Staub M, Sasvari M, Spasokukotskaja T, Piroth Z, Kazimierczukz F (1996): Human Tonsillar lymphocytes as targets for immunosuppressive and anticancer drugs. Acta Otolaryngol Suppl Stockh 523:124-7.

27. Taketa K (1990): Alpha-fetoprotein: reevaluation in hepatology. Hepatology 12:1420-1432.

28. Tarao K, Rino Y, Okaawa S, Shimizu A, Tamai S, Miyakawa K, Aoki H, Imada T, Shindo K, Okamoto N, Totsuka S (1999): Association between high serum alanine aminotransferase levels and more rapid development and higher rate of incidence of 
heptocellular carcinoma in patients with hepatitis $\mathrm{C}$ virus-associated cirrhosis. Cancer 86:589-595.

29. Velazquez RE, Rodriguez M, Navascues CA, Linares A, Perez R, Sotorrios NG, Martinez I, Rodrigo L (2003): Prospective analysis of risk factors for hepatocellular carcinoma in patients with liver cirrhosis. Hepatology 37:520-527.

30. Wakui K, Kumata H, Tadaki H, Yamagata S (1986): Clinical significance of serum glutathione reductase in various clinical conditions, specially in liver diseases. Tohoku, J EXP Med 118(1):1723.

31. Wilson JF (2005): Liver Cancer on the Rise. Annals of Internal Medicine 142 (12): 1029-1032.
32. Yao FY (1999): Elevated alpha-fetoprotein levels in heptocellular carcinoma. AJG 338: 7.

33. Yoshida S, Kurokohchi K, Arima K, et al. (2002): Clinical significance of lens culinaris agglutinin-reactive fraction of serum alpha-fetoprotein in patients with heptocellular carcinoma. Int $\mathbf{J}$ Oncal 20:305-309.

34. Yoshioka M, Itoh M, Akizawa T, Hirose K. (1997): A new method is developed for the detection of 2'-deoxycytidine. J Pharm Biomed Anal 17(21-22):1382-89 .

35. Yu MC, Yuan JM, Govindarajan S, Ross RK (2000): Epidemiology of hepatocellular carcinoma. Can J Gastroenterol 14: 703709. 


\section{قياس 2-دى أوكسى سيتدين كلاليل بيولوجى لسرطان الكبد}

وفاء عبد الله أحمد1 - منار محمد منير2 - مها أبو شادى 3 - هبة حسنى منصور $-4$

ناهد عبد الوهاب5 - ماساتورى يوشوكا6" - محمود المرزبانى

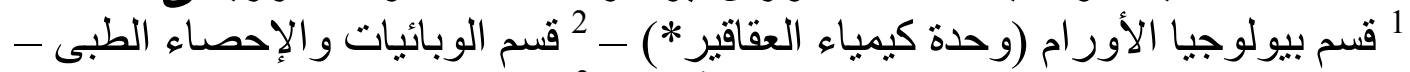

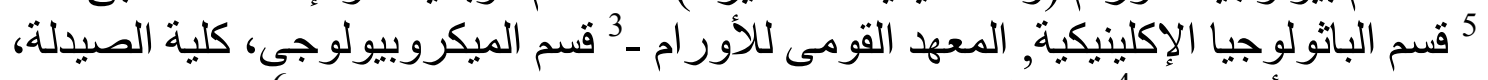

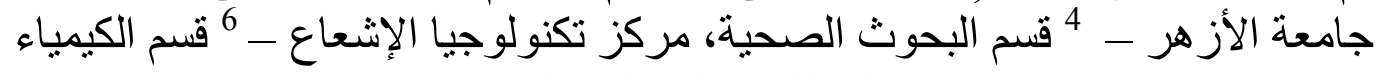
التحليلية، كلية الصيدلة، جامعة ستسونان، أوساكا، اليابان

يعتبر 2-دى أوكسى سيتدين واحد مـن أربعـة نيكلويوتيدات معروفة وموجودة فى الجى

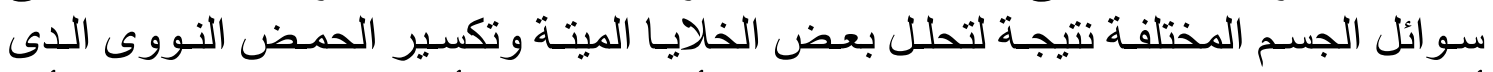

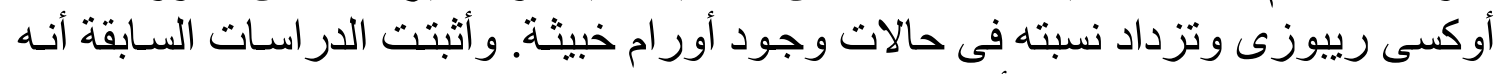

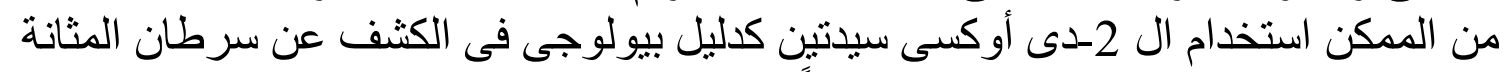

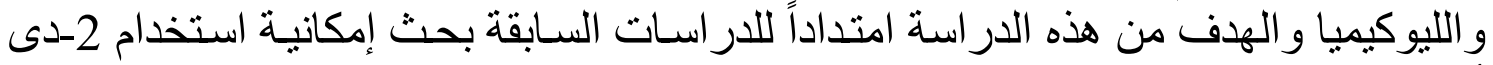

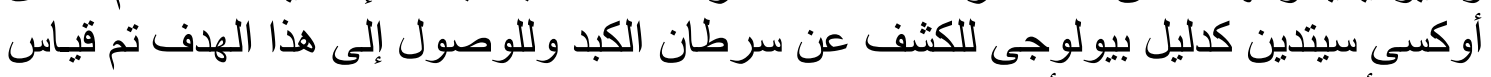

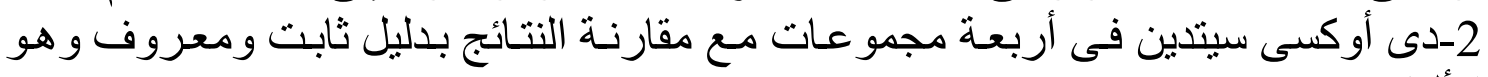
الألفا فيتوبروتين.

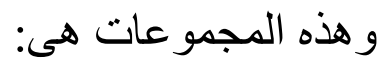
مرضى سرطان الكبد (60 مريضناً)

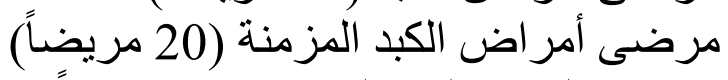

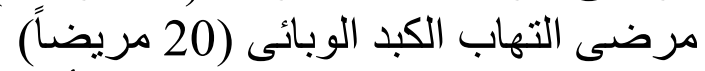
المجمو عة الضابطة و عددها 20 من الأفر اد الأصحاء.

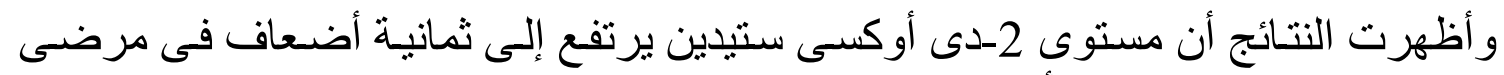

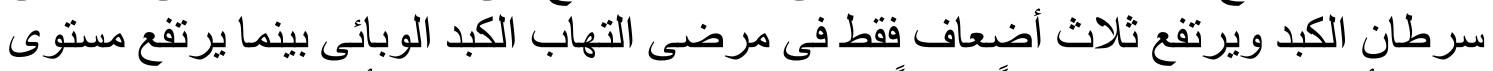

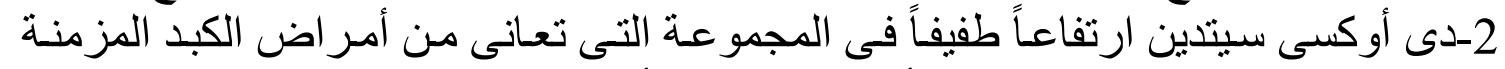

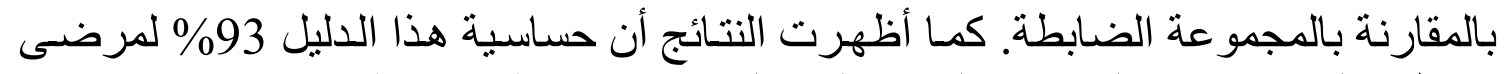
سرطان الكبد و 90\% لمرضى التهاب الكبد الوبائى عند قيمة مرجعية مقدار ها

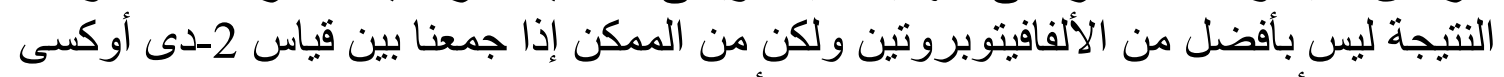

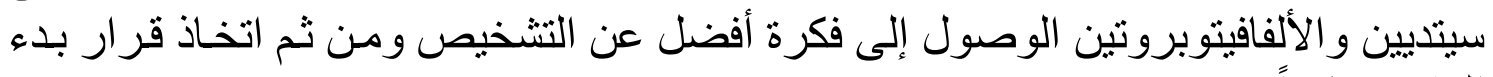
العلاج مبكراً. 